\title{
FAILURE OF DESOXYCORTICOSTERONE GLUCOSIDE TO ALTER CEREBRAL VENOUS SUGAR CONCENTRATION IN MAN ${ }^{1}$
}

\author{
By JAMES F. SCHIEVE ${ }^{2}$ AND WILLIAM P. WILSON \\ (From the Departments of Medicine and Psychiatry, Duke University School of \\ Medicine, Durham, N. C.)
}

(Received for publication June 27, 1952; accepted August 12, 1952)

Intravenous administration of desoxycorticosterone glucoside (DCG) in man has been reported to cause an immediate liberation of sugar from the brain into cerebral venous blood (1). It is said that a portion of this reducing substance may be galactose rather than glucose as it is non-fermentable (1). The finding in the fasting state of blood glucose levels higher in blood draining an organ than in the blood entering it is unusual except in the liver. As the reported findings postulated a new physiological concept, an attempt was made to confirm these studies.

In the original report, the rise in sugar concentration in internal jugular blood was found after the injection of DCG and during the period of inhalation of 15 per cent $\mathrm{N}_{2} \mathrm{O}$. As these procedures were reported not to cause a change in cerebral blood flow or cerebral oxygen consumption (1), only measurements of blood sugar content were made following 1) intravenous DCG and 2) inhalation of 15 per cent and 50 per cent $\mathrm{N}_{2} \mathrm{O}$.

\section{METHOD}

Seven physically normal subjects were studied in the fasting state. Blood specimens were obtained from the femoral artery and from the internal jugular vein (2). After control specimens were taken, DCG ${ }^{3}$ (50 mg. in 5 cc. water containing $10 \%$ glucose and $10 \%$ acetamide) was given intravenously into an antecubital vein over a time period of one minute. Simultaneously drawn arterial and cerebral venous blood samples were taken at frequent intervals from one to fifteen minutes after injection.

All blood sugar determinations were done in duplicate, using Nelson's (3) modification of the Somogyi method for measuring blood glucose.

1 This investigation was supported, in part, by a research grant from the National Institutes of Health, U. S. Public Health Service.

2 American Heart Association Fellow. Present address: Ohio State University, Columbus, Ohio.

3 The desoxycorticosterone glucoside used in this study was generously supplied by the Ciba Pharmaceutical Products, Inc., Summit, New Jersey.
RESULTS

In Table I are given the simultaneous arterialcerebral venous sugar differences in six subjects after intravenous administration of $50 \mathrm{mg}$. of DCG. No change in $\mathrm{A}-\mathrm{V}$ difference or in blood sugar level occurred.

Table II shows the effect of 15 per cent and 50 per cent $\mathrm{N}_{2} \mathrm{O}$ on blood sugar levels and on arterial-cerebral venous sugar difference. The results are those obtained on one subject after inhalation of 15 per cent $\mathrm{N}_{2} \mathrm{O}$ over a period of 10 minutes and, after inhalation of 50 per cent $\mathrm{N}_{2} \mathrm{O}$ over a second 10 -minute period. The patient noted slight drowsiness with the second procedure but no other symptoms.

\section{DISCUSSION}

DCG, in the dosage used, did not significantly change blood sugar levels or arterial-cerebral venous blood sugar difference. The slight immediate, but brief, increase in both arterial and cerebral

TABLE I

Effect of intravenous administration of $50 \mathrm{mg}$. of desoxycorticosterone glucoside on arterial-cerebral venous glucose differences

(All values are given in $\mathrm{mg} . \%$ )

\begin{tabular}{l|r|r|r|r|r|r|r}
\hline \hline & Con- & \multicolumn{5}{|c}{ Time in minutes (after DGG) } \\
\cline { 2 - 7 } & trol & 2 & 4 & 6 & 8 & 10 & 15 \\
\hline J. S. & 10.9 & 13.1 & 14.0 & 12.6 & & 16.1 & 15.2 \\
D. B. & 13.7 & 13.0 & 13.2 & 12.6 & 12.0 & 9.0 & \\
B. V. & 11.7 & 13.3 & 16.9 & 14.3 & & 14.9 & \\
S. S. & 12.0 & 15.9 & 12.3 & 12.3 & & 10.6 & 12.3 \\
N. P. & 12.0 & 10.0 & 8.7 & 8.0 & 10.7 & & 12.3 \\
B. S. & 11.3 & 13.5 & 13.9 & 11.3 & 10.6 & & \\
\hline Mean & 11.9 & 13.1 & 13.2 & 11.9 & & 12.4 & \\
Avg. art. blood & 96.1 & 98.1 & 96.2 & 94.0 & & 93.6 & \\
$\quad$ sugar, mg. \% & & & & & & & \\
Avg. cerebral & 84.0 & 85.0 & 83.0 & 82.1 & & 81.2 & \\
$\quad$ venous blood & & & & & & & \\
\hline
\end{tabular}


TABLE II

Effect in one subject of $15 \%$ and $50 \% \mathrm{~N}_{2} \mathrm{O}$ on arteriab-cerebral venous glucose differences

(All values are given in $\mathrm{mg} . \%$ )

\begin{tabular}{|c|c|c|c|c|c|c|c|c|c|c|c|c|}
\hline \multirow{2}{*}{ Minutes } & \multicolumn{2}{|c|}{ Before $\mathrm{N}_{2} \mathrm{O}$} & \multicolumn{10}{|c|}{ During $15 \% \mathrm{~N}_{2} \mathrm{O}$ breathing } \\
\hline & -4 & -2 & 1 & 2 & 3 & 4 & 5 & 6 & 7 & 8 & 9 & 10 \\
\hline $\begin{array}{l}\text { 1) Arterial, mg. } \% \\
\text { 2) Cerebral venous } \\
\text { 3) A-V sugar difference }\end{array}$ & $\begin{array}{r}118.3 \\
109.6 \\
8.7\end{array}$ & $\begin{array}{r}117.7 \\
109.6 \\
8.1\end{array}$ & & $\begin{array}{r}118.8 \\
108.5 \\
10.3\end{array}$ & & $\begin{array}{r}117.7 \\
106.0 \\
11.7\end{array}$ & & & $\begin{array}{r}116.7 \\
102.9 \\
13.8\end{array}$ & & & $\begin{array}{r}112.1 \\
102.9 \\
9.2\end{array}$ \\
\hline \multirow{2}{*}{ Minutes } & \multicolumn{2}{|c|}{ Before $\mathrm{N}_{2} \mathrm{O}$} & \multicolumn{10}{|c|}{ During $50 \% \mathrm{~N}_{2} \mathrm{O}$ breathing } \\
\hline & -4 & -2 & 1 & 2 & 3 & 4 & 5 & 6 & 7 & 8 & 9 & $10 \cdot$ \\
\hline $\begin{array}{l}\text { 1) Arterial, mg. \% } \\
\text { 2) Cerebral venous } \\
\text { 3) A-V surgar difference }\end{array}$ & $\begin{array}{r}108.5 \\
95.7 \\
12.8\end{array}$ & $\begin{array}{r}106.5 \\
96.3 \\
10.2\end{array}$ & $\begin{array}{r}105.0 \\
95.7 \\
9.3\end{array}$ & $\begin{array}{r}103.4 \\
96.8 \\
6.6\end{array}$ & $\begin{array}{r}103.9 \\
96.8 \\
7.1\end{array}$ & • & & $\begin{array}{r}106.0 \\
98.8 \\
7.2\end{array}$ & & & & $\begin{array}{r}103.4 \\
96.8 \\
6.6\end{array}$ \\
\hline
\end{tabular}

venous glucose blood levels is related to the glucose content used as a solvent for the DCG. This amounts to $500 \mathrm{mg}$. of glucose ( $5 \mathrm{cc}$. of DCG is dissolved in 10 per cent glucose and 10 per cent acetamide). This amount would be rapidly dispersed into body tissues and the degree of blood sugar rise in the blood stream would be related to amount of sugar injected, rate of injection, and the time following injection. If all injected glucose remained intravascularly, $500 \mathrm{mg}$. would theoretically raise the glucose level about $10 \mathrm{mg}$. per cent in a man of average size.

\section{SUMMARY AND CONCLUSIONS}

1. Desoxycorticosterone glucoside, in the dosage used, did not narrow arterial-cerebral venous glucose difference. In no instance did cerebral venous blood sugar content surpass or approach arterial levels.

2. Nitrous oxide in 15 per cent and 50 per cent concentrations, in one patient, did not cause an increase in the cerebral venous blood glucose content.

\section{REFERENCES}

1. Bentinck, R. C., Gordan, G. S., Adams, J. E., Arnstein, L. H., and Leake, T. B., Effect of desoxycorticosterone glucoside upon cerebral blood flow and metabolism of human subjects. J. Clin. Invest., 1951, 30, 200.

2. Myerson, A., Halloran, R. D., and Hirsch, H. L., Technic for obtaining blood from the internal jugular vein and internal carotid artery. Arch. Neurol. \& Psychiat., 1927, 17, 807.

3. Nelson, N., A photometric adaptation of the Somogyi method for the determination of glucose. J. Biol. Chem., 1944, 153, 375. 